\title{
Netizens' Reaction to the Garbage Prank Case: Forensic Linguistic Perspective Analysis
}

\author{
Nadiya Lathifah Hani ${ }^{*}$ \\ ${ }^{1}$ Postgraduate Indonesian Language and Literature Education, Yogyakarta State University \\ *Corresponding author. Email: Nadiya.lathifah@gmail.com
}

\begin{abstract}
The purpose of this study is to analyze the reactions of netizens to prank cases FD from the point of view of forensic linguistics. Research methods used in research "Forensic Linguistic View Regarding Warganet's Reaction To This Garbage Prank Case" is a qualitative descriptive research. Sources of data in this study are layer capture (screenshot) on the writings of netizens on social media Twitter, Instagram, Facebook, and Youtube comments column. Data collection in this study using the listening and note-taking technique. Data analysis was carried out by outlining the writings of the netizens are then analyzed related to the use of the language that associated with applicable laws. The results of this study show that the various comments of the netizens seemed to be cornering and did not give space for FP to be able to realize his mistake. Not everyone has a big heart dared to admit his mistake. FP tried to run away first before finally arrested.
\end{abstract}

Keywords: warganet, prank, youtuber, forensic linguistics

\section{PRELIMINARY}

Youtube is one of the platforms that is currently being favored by many public people. This website contains videos that can be accessed by anyone, can be accessed by anyone, and uploaded by anyone. Therefore, Youtube is one of the most profitable business opportunities worth a try. There have been many Youtubers circulating (calls for people who create contenton Youtube) create various content of their creativity which is then uploaded to Youtube. In this global era, it is undeniable that every information provider platform has its advantages and disadvantages, Youtube is no exception. Lots of people whouse it for example to share their activities which are commonly called Vlogs, there are those who do business such as product advertisements and react to a product or alsodo a live stream that can directly interact with the audience and some various content such as music content, movies, the process of making something, usesomething or a review of a particular product or event.

For content creators, Youtube also provides benefits by providing a 'salary' because Youtube has collaborated with AdSense, which is an advertising cooperation program in Indonesia's social media hosted by Google. Account owner like Youtube or blogger that you can register an account on the
AdSense site first, after that the ads will appear installed on their account where the account owner will get income from every advertisements that are clicked by visitors to the site (pay per click (PPC)). Apart from that AdSense tooprovides revenue from searches on google and also advertising referrals (referrals). Foraudience, various information can be accessed easily. Besides, there are many people who make videos with the same theme, so viewers can choose which videos liked and can be used as a reference.

Quoted from

https://www.Youtube.com/intl/id/about/ that Youtube has a mission to give everyone freedom of expression and show the world. There are four basic values determined by Youtube, namely freedom of expression, free domin formation, freedom to use opportunities, and freedom to have a placework. Of course, these various freedoms have content that is less acceptableby society. One of the content creators with the initials FP recently caused an uproar warganet (internet citizen) with the content he created on his Youtube Channel. Contentit was uploaded on May 1, 2020 at around 01.30 WIB with the title "Prank Love "Food to Sissy CBL". It is known, now the video has been removed from the FP account. This Content makes Indonesian angry because FP's actions provide assistance to trans 
women. Suddenly, contentit immediately went viral not long after it was uploaded. Netizens give a lotridicule and scorn.

After the video went viral, it turned out that FP ran away so he was included in the Search List People (DPO) by the police. Bandung Police Chief, Kombes Pol Ulung Sampurna Jaya quoted from https://www.liputan6.com/ explained that his party will continue to search for his where about FP. Not long on the run, FP was arrested at the Merak Toll Road on Friday, 8 May 2020 early morning. FP was arrested without a fight to the police. Before being arrested, FP made a short video on Instagram on his instastory feature containing an apologybut not serious. Wearing a pink long-sleeved shirt with a hood he said, "I personally apologize for my behavior... but it's a lie!". Automatically,This fake apology video was berated by netizens.

Netizens' comments varied. Some blaspheme, some giveinput to FP so as not to repeat his behavior. The blasphemous speech acts of netizensalso not completely justified. Chaer [1] states that speech actsis an individual symptom, psychological in nature and its continuity is determined bythe speaker's language ability in dealing with certain situations. Based on expert understanding-The expert concluded that utterances can have a bad effect on usersspeech act itself. According to Leoni (in Sumarsono, and Paina Partama, 2010:329-330) speech acts are part of speech events, and speech events are part of speech events speech situation. Each speech event is limited to activities, or aspects of activities thatdirectly governed by rules or norms for speakers.

This speech act in the form of Warganet's comments will be studied from a linguistic point of viewforensics. Olsson [2] argues that forensic linguistics is a relationship between language, crime, and the law in it, including law enforcement, evendisputes that have the potential to involve some violation of the law aimed atget a legal solution. There are also things that are the main concern in linguistics forensics according to Coulthard [3] and Johnson [3] states that the main concern offorensic linguistics, namely (1) the language of legal documents; (2) the language of the enforcement policelaw; (3) interviews with vulnerable children or witnesses in the legal system; (4)interactions in the courtroom; (5) linguistic evidence and expert testimony in court;(6) authorship and plagiarism; and (7) forensic phonetics and speaker identification.

So, thing There are seven main concerns in forensic linguistics. Those seven things are interconnected with each other and cannot be separated Previous research that is relevant to this research is Dini .'s research Nuranjani [4]entitled "Controversy of Warganet's Speech on the Use of \#Justiceforaudrey and \#Audrey is also guilty in Bullying Case Based on Forensic Linguistic Approach". Based on the results of this study, there are several forms of speech, including: forms of humiliation, defamation, provocation, spreading false news, and inciting form. Hate speech has an impact on exclusion, discrimination, violence, hatred of individuals and groups, and group hostility. Then, research conducted by Sriyanto [5] entitled "The Use of Language in Social Media "Forensic Linguistics Review: A Case Study of Language Use in Twitter". Results Research shows that the use of language in social media can be divided into: four categories. The four categories are as follows: (1) data that can be categorized as blasphemy or defamation, (2) data that can be categorized as slander, (3) data that can be categorized as minor insults, and (4) data that does notcan be categorized as writing that violates the law.

Based on previous studies, the use of language in speech and writing penetrated into the realm of law. The rampant bullying is getting more and more enliven this research in the field of forensic linguistics. The aim of this research isto analyze the reactions of netizens to the FD prank case from a linguistic point of view forensics. Therefore, this research is entitled "A Forensic Linguistic View Regarding Reaction". Warganet Against Garbage Prank Cases".

\section{RESEARCH METHODS}

The research method used in the research "Forensic Linguistic View" Regarding Warganet's Reaction to the Garbage Prank Case, this is through research descriptive qualitative. The source of data in this study is the layer capture (screenshot). on the writings of netizens on social media Twitter, Instagram, Facebook, and the column Youtube comments. Data collection in this study used the listening and reading technique note. Data analysis was carried out by outlining the writings of netizens then an analysis is carried out related to the use of the language associated with current regulation. Validation of data using triangulation, namely with observing the same object in various situations. In this case, various instruments (test the results of presenting review texts, interviews, field notes and questionnaires) get the same information.

\section{DISCUSSION}

The data obtained from netizen comments related to this FP case were collected as many as 30 comment. Consists of 8 comments from one of the videos on the FP Youtube Channel entitled "In fact, so Kuproy" which was uploaded on April 23, 2020, the tweets of many netizens on Twitter were 5 comments, 4 netizens' Facebook posts, and comments on the account lambe turah about FP as much as 10 comments. Discussion of the contents of the comments will be carried out oneone by one according to the order of social media mentioned 
above. The following is a discussion of these comments.

\subsection{FP YouTube Channel}

FP's YouTube Channel owns when this article was written on May 14, 2020 as many as 149 thousand subscribers with a total viewer of all videos of 9,433,984 time. Joined YouTube on November 26, 2019, which is still relatively new. Channel it has the following description "Toxic humble and chill. my content contains all absurd things, so don't expect anything about education on this channel and if you don't understand or butter, it's okay, I'm really stupid h3h3". The following table is a discussion on each netizen comments at YouTube channel.

\begin{tabular}{|c|c|c|}
\hline \multirow[t]{2}{*}{1} & OS Speech & $\begin{array}{l}\text { Semenjak kena kasus prenk yang komen pada banyak } \\
\text { ya ilahh ngapain Lo pada mampir kalaw mau ngehujat } \\
\text { mah apah beda nya Lo sama dia sama*a gak punya otak } \\
\text { emang }\end{array}$ \\
\hline & Lingual maker & "gak punya otak emang" \\
\hline \multirow[t]{2}{*}{2} & NGC Speech & $\begin{array}{l}\text { Woi sampah masyarakat, g punya otak lu. } \\
\text { Situasi lagi kaya gini ngeprank lu g jelas, biadab kau anak } \\
\text { muda }\end{array}$ \\
\hline & Lingual maker & "g punya otak" dan "biadab kau" \\
\hline \multirow[t]{2}{*}{3} & N Speech & Mukaa" DAJALLL LAKNATT \\
\hline & Lingual maker & "Mukaa" DAJALLL LAKNATT" \\
\hline \multirow[t]{2}{*}{4} & OFO Speech & $\begin{array}{l}\text { Tolol nya kebangetan. Minta maaf saat udah menyesal. } \\
\text { Kemaren kemaren kemana aja. Bukan mikir dulu sebelum } \\
\text { buat konten. Apa itu cocok atau tidak durasi video nya?. } \\
\text { Tangkap ajaa pak }\end{array}$ \\
\hline & Lingual maker & "Tolol" dan "Tangkap ajaa pak" \\
\hline \multirow[t]{2}{*}{5} & KK Speech & $\begin{array}{l}\text { Gw nunggu kabar baik dari ferdian } \\
\text { Mati gantung diri gara" stres }\end{array}$ \\
\hline & Lingual maker & "kabar baik dari ferdian, Mati gantung diri" \\
\hline \multirow[t]{2}{*}{6} & A2O Speech & Anak dangak !!! Otak lu geser jauh dari tempatnya \\
\hline & Lingual maker & "Anak dangak" \\
\hline \multirow[t]{2}{*}{7} & AH Speech & $\begin{array}{l}\text { BABI KAU SETAN, MANUSIA KURANG AJAR, } \\
\text { ELUH LAHIR KAGA KAMAT APA, BORO" GUE } \\
\text { MAU SUBSCRIBE CHANNEL LUHH, GA GUNA, } \\
\text { ISENGIN WARGA GA BRSALAH, DASAR BABI } \\
\text { ANJING KAUU..!! }\end{array}$ \\
\hline & Lingual maker & $\begin{array}{l}\text { "BABI KAU SETAN" dan "DASAR BABI ANJING } \\
\text { KAUU" }\end{array}$ \\
\hline \multirow[t]{2}{*}{8} & IX Speech & $\begin{array}{l}\text { Woy Jancok.... Lu jadi DPO ya?? } \\
\text { lo sepertinya harus makan sampah dulu deh.. biar bisa } \\
\text { ngerasain gimana jadi orang tapi gak di hargai... }\end{array}$ \\
\hline & Lingual maker & "Jancok." dan "harus makan sampah dulu deh" \\
\hline
\end{tabular}

Table 1 Netizen Comments at Youtube Channel

The statements from the netizens with the initials OS, NCG, N, OFO, A2O, AH, and IX above can be subject to article on insult/ defamation with Article 45 paragraph 3 reads: Any person who knowingly and without rights distributes and/or transmit and/or make accessible Electronic Information and/or Electronic Documents containing insults and/or defamation as referred to in Article 27 paragraph (3) shall be punished with imprisonment of at most 4 (four) years and/or a maximum fine of $\mathrm{Rp}$. $750,000,000.00$ (seven hundred five tens of millions of rupiah).
Then, there were some netizen comments with the initials OFO, KK, and IX Linguistically signifies a provocative sentence. This is regulated in Article 28 Paragraph (2) The ITE Law regulates "Everyone intentionally and without rights disseminates information which is intended to cause hatred or hostility to individuals and or certain community groups based on ethnicity, religion, race, and intergroup (SARA)". The threat of violators of this article is a maximum imprisonment of 6 (six) years and/or a maximum fine of Rp. $1,000,000,000.00$ (one billion rupiah). Then, there Also Article 156 of the 
Criminal Code stipulates "Whoever publicly declares "feelings of hostility, hatred or condescension towards one or more ethnic groups Indonesia was sentenced to a maximum imprisonment of four years with a maximum fine of four thousand five hundred rupiah.".

\subsection{Twitter}

Citizens' utterances on Twitter social media use the perpetrator's name hashtag. In addition, the hashtag has been trending for a while on twitter some time ago to be precise in early 2020. The author is having trouble finding tweets from Indonesian citizens who use Indonesian as their primary language. This too signifies that the power of social media can jump-start news across various countries. Here are some examples of netizen comments regarding the case FP. The following table is some examples of netizen comments regarding the case FP.

\begin{tabular}{|c|l|l|}
\hline 1 & F Speech & $\begin{array}{l}\text { Kalau meninggal kayaknya akan tetep dicengin ya sama masyarakat... } \\
\text { Semoga amal ibadahnya diterima... tapi boong }\end{array}$ \\
\cline { 2 - 4 } & Lingual maker & $\begin{array}{l}\text { "Kalau meninggal kayaknya akan tetep dicengin" dan "Semoga amal } \\
\text { ibadahnya diterima" }\end{array}$ \\
\hline 2 & RG Speech & $\begin{array}{l}\text { Si anjing. Masih sok relijius dan bermoral. @FP, you're the real definition of } \\
\text { fucktard. }\end{array}$ \\
\cline { 2 - 4 } & Lingual maker & "Si anjing" \\
\hline \multirow{2}{*}{3} & S Speech & Rest In Peace ndess \#FP \\
\cline { 2 - 4 } & Lingual maker & "Rest In Peace ndess" \\
\cline { 2 - 4 } & Lingual maker & $\begin{array}{l}\text {.kcuali yg bangsat kek FP, penimbun masker, etc.. I'll show them no mercy. } \\
\text { "borry, I'm not a saint. I act accordingly. }\end{array}$ \\
\hline 5 & LZ Speech & $\begin{array}{l}\text { Enjoy for watching, kata kalian! } \\
\text { Membuat konten tak manusiawi dan meminta khalayak untuk } \\
\text { menikmatinya???? } \\
\text { Sungguh sungguh jahannam! } \\
\text { Mati hati nurani kalian huhhhh } \\
\text { Catat namanya :FD! }\end{array}$ \\
\cline { 2 - 4 } & "Sungguh sungguh jahannam!" \\
\hline
\end{tabular}

Table 1 Netizen Comments at Twitter

The words from the netizens with the initials RG, S, PHN, and LZ above can be subject to articles regarding insult/defamation with Article 45 paragraph 3 with imprisonmenta maximum of 4 (four) years and/or a maximum fine of Rp fifty million rupiah). While the netizen with the initial F commented on the marker lingually can be subject to Article 45 paragraph 4: Any person who intentionally and without the right to distribute and/or transmit and/or make access to Electronic Information and/or Electronic Documents that have extortion and/or threats as referred to in Article 27 paragraph (4) sentenced to a maximum imprisonment of 6 (six) years and/or a maximum fine of IDR 1,000,000,000.00 (one billion rupiah).

Finally, still with a citizen with the initial $\mathrm{F}$ the comment can also contain SARA which is subject to Article 45A paragraph 2: Any person who intentionally and without the right to disseminate information intended to incite hatred orhostility of certain individuals and/or community groups based on ethnicity, religion, race, and intergroup (SARA) as referred to in Article 28 paragraph (2) shall be sentenced to a maximum imprisonment of 6 (six) years and/or a maximum fine ofIDR 1,000,000,000.00 (one billion rupiah).

\subsection{Facebook}

Most of the posts on Facebook are spread of news about FP but accompanied by comments about the news. Indeed, not all news commented by someone who uploaded it. Still, there are things that must be seen together regarding the comments of netizens, as follows. The following table is an image of netizen comment at Facebook.

\begin{tabular}{c|c|l|}
1 & PV Speech & $\begin{array}{l}\text { Kelakuan Asli FP, emang gini anjirr kelakuannya } \\
\text { mampus sekarang udah ketangkap diaa }\end{array}$ \\
\hline
\end{tabular}




\begin{tabular}{|c|c|c|}
\hline & $\begin{array}{l}\text { Lingual } \\
\text { maker }\end{array}$ & "mampus sekarang udah ketangkap diaa" \\
\hline \multirow[t]{2}{*}{2} & PC Speech & $\begin{array}{l}\text { Akhirnya tertangkap juga nih buronan netizen }+62 \text { makasih polisi kerja } \\
\text { kerasnya. }\end{array}$ \\
\hline & $\begin{array}{l}\text { Lingual } \\
\text { maker }\end{array}$ & "buronan netizen $+62 "$ \\
\hline \multirow[t]{2}{*}{3} & $\begin{array}{l}\text { HZRN } \\
\text { Speech }\end{array}$ & 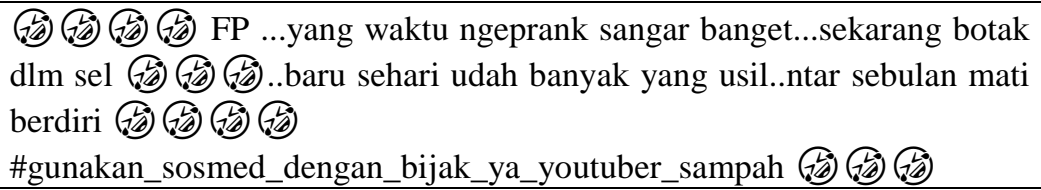 \\
\hline & $\begin{array}{l}\text { Lingual } \\
\text { maker }\end{array}$ & $\begin{array}{l}\text { "ntar sebulan mati berdiri” dan } \\
\text { "\#gunakan_sosmed_dengan_bijak_ya_youtuber_sampah" }\end{array}$ \\
\hline \multirow[t]{2}{*}{4} & JH Speech & $\begin{array}{l}\text { Youtuber yg Gk Ada akhlak akhirnya ketangkep... } \\
\text { Makan tu sampahmu!!! } \\
\text { Kmren masih bisa bnyak gaya.. } \\
\text { Skrg bisa apa lo? } \\
\text { Yg sampah msyarakat tu sbnernya km @FP }\end{array}$ \\
\hline & $\begin{array}{l}\text { Lingual } \\
\text { maker }\end{array}$ & $\begin{array}{l}\text { Kelakuan Asli FP, emang gini anjirr kelakuannya (rob) } \\
\text { mampus sekarang udah ketangkap diaa }\end{array}$ \\
\hline
\end{tabular}

Table 2 Netizen Comments at Facebook

The words from the netizens with the initials PV, PC, HRZN, and JH above can be subject to articles regarding insult/defamation with Article 45 paragraph 3 with imprisonmenta maximum of 4 (four) years and/or a maximum fine of Rpfifty million rupiah). Then the netizen with the initials HRZN can be sentenced again Article 45 paragraph 4: with a maximum imprisonment of 6 (six) years and/or a maximum fine of $1,000,000,000.00$ (one billion rupiah) for his act of threatening someone.

\subsection{The Comment Column for The 'Lambe Turah' Account}

Lambe turah is one of the accounts on Instagram that often uploads viral news. Starting from bullying, theft, to good deeds. Lambe Turah joined Instagram on July 28, 2015. This account is located in Indonesia based on the data in the 'about this account' option in the profile Lambe Turah. The following will display the comments of netizens on one of the following: Lambe Turang's post about FP that became news in one of the letters news in the United Kingdom (UK) with the title "Youtuber Arrested After Handing Out "Boxes of Rubish Disguised as Food" uploaded on 10 May 2020. The following table is an image of netizen comment at 'Lambe Turah' Account.

\begin{tabular}{|c|l|l|}
\hline \multirow{2}{*}{1} & M Speech & Bentar lagi diundang jadi Youtuber di Inggris.. tapi boong \\
\cline { 2 - 3 } & Lingual maker & "Bentar lagi diundang jadi Youtuber di Inggris" \\
\hline \multirow{2}{*}{2} & GP Speech & Mantap peerr biar tau kalua di negara +62 ada manusia kayak elu anjing \\
\cline { 2 - 3 } & Lingual maker & "manusia kayak elu anjing" \\
\hline \multirow{2}{*}{3} & C Speech & KON NGERTI JANCOK OPO GAK PEEEEEERRRRR \\
\cline { 2 - 3 } & Lingual maker & "jancok" \\
\hline \multirow{2}{*}{4} & R Speech & Gblk gblkkkk \\
\cline { 2 - 3 } & Lingual maker & blk gblkkkk \\
\hline 5 & IN Speech & Goblognya go internasional \\
\hline & & "goblognya" \\
\hline 6 & AT Speech & Go internasional anjeng \\
\hline & & "anjeng" \\
\hline 7 & P Speech & Hahaha mampos \\
\hline & & Mampos \\
\hline 8 & A Speech & Mati kau peerr \\
\hline & & "mati kau" \\
\hline 9 & M Speech & Mampus lo per di bantai ama genk pelangi lo perrr surem bat idup lu \\
\hline & & "mampus" \\
\hline
\end{tabular}




\begin{tabular}{|l|l|l|}
\hline 10 & A Speech & $\begin{array}{l}\text { Gaada akhlak emang lo per per. Terkenal karna prestasi kek perrr. Prestasi } \\
\text { kagak ada. Terkenal kaya beginian perr }\end{array}$ \\
\hline & & "gaada akhlak" \\
\hline
\end{tabular}

Table 3 Netizen Comments at 'Lambe Turah' Account

Peeches from netizens with the initials M, GP, C, R, IN, AT, and A above can be subject toArticle on humiliation/defamation with Article 45 paragraph 3 with a criminal imprisonment for a maximum of 4 (four) years and/or a maximum fine of $\mathrm{Rp}$ (seven hundred and fifty million rupiah). Meanwhile, the netizens with the initials $\mathrm{P}, \mathrm{A}$, and $\mathrm{M}$ ) abovethe act of threatening someone can be sentenced to Article 45 paragraph 4: with imprisonmenta maximum of 6 (six) years and/or a maximum fine of $\mathrm{Rp}$. $1,000,000,000.00$ (one billionrupiah).

\section{CONCLUSION}

The various netizen comments seem to be cornering and do not provide spaceto FP to be able to realize his mistake. Not everyone has a big heart right away dare to admit his mistakes. FP tried to run away first before finally arrested. Recently, there has even been a video circulating of FP hacking by senior detainees in prisons(jail). In cases like this, the perpetrator must have made a mistake. Quotedfrom https://www.cnnindonesia.com/ that FP can be charged with Article 45 Paragraph 3 of the Law Information and Electronic Transaction (ITE) law. Head of West Java Police Public Relations
Commissioner Saptono Erlangga said that the disclosure of this case began with a report the police on behalf of Ferdi Hermawan with the time of the incident on May 1, 2020 at 02.00 WIB.

\section{REFERENCES}

[1] A. Chaer, Kesantunan Berbahasa., Jakarta: Rineka Cipta., 2010.

[2] J. Olsson, Forensic Linguistics, New York: Continuum Internasional Publishing Group, 2008.

[3] M. d. J. A. Coulthard, An Introduction to Forensic Linguistics, Language in Evidence., New York: Routledge Taylor \& Francis Group., 2007.

[4] D. Nuranjani, "Kontroversi Tuturan Warganet pada Penggunaan \#Justiceforaudrey dan \#Audreyjugabersalah dalam Kasus Bullying Berdasarkan Pendekatan Linguistik Forensik," 2019. 